\title{
Changing perspectives on the Crusades
}

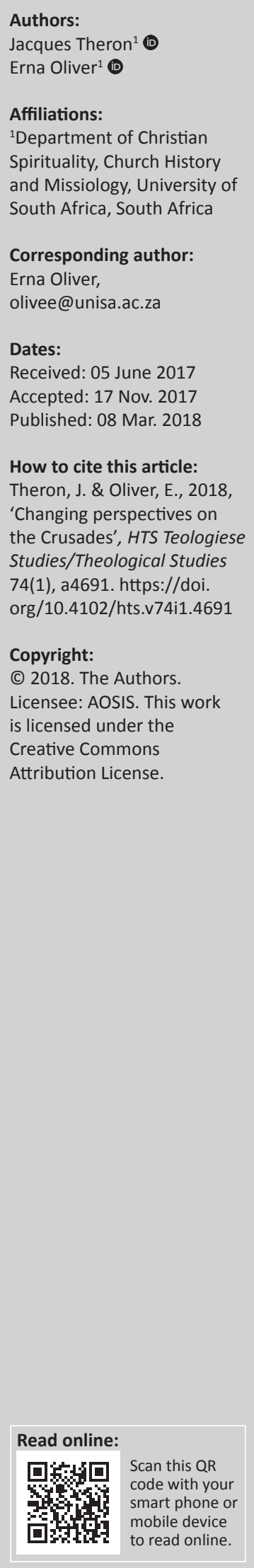

The notion and consequences of the Crusades are still influencing the modern Christian (and Muslim) pattern of thinking. These 'holy wars', fought by members of the Roman Catholic Church, mostly against infidels ('unbelievers'), including the Muslims of the time, lasted for several centuries and had varied levels of success. These wars were both lauded and criticised and currently these two opposite perceptions still persist. After the background to the historical setting of the Crusades, this article provides an overview of the changing viewpoints on this movement by describing the perspectives of the most prominent authors (exponents) who aired their views on the Crusades between the 16th century and the first part of the 21st century, finding that the negative perception runs like a thread through the last five centuries.

\section{Introduction}

George Orwell, in his famous publication Nineteen Eighty-four (Orwell 1949:37), declared that those who control the past also control the future, while people who control the present are the ones who are controlling the past. This statement referred to the practical implications of the concept of historical revisionism that implies that history is written from the perspective of the dominant class (Gundani 2004:76). Reinterpretation of historical events from different perspectives can also occur because of the discovery of new evidence or when time brings distance and greater objectivity about traumatic events. Two examples will suffice: (1) Mommsen (2009:74) called the changing historical perspective by the Germans on events focused around the Nazi dictatorship a 'generational shift' that needed time and distance and the disclosing of large volumes of previously unknown evidence in order to change the general public's interpretation of the past; and (2) South Africans are still too close to the 'collective traumas of the past' (Nytagodien \& Neal 2004:376) for the generational shift to have a positive effect (cf. Oliver 2011):

The history of history is increasingly fashionable. All history is revisionist, a response to what others have written ... Revision is, or should be, as inherent in the study of history as interpreting evidence. (Tyerman 2011:1, 233)

These comments made by Tyerman in the Introduction of his renowned book, The Debate on the Crusades, 1099-2010, also apply to this discussion of the literature being published on the Crusades since the 16 th century. The Crusades ${ }^{1}$ represent one of the most interesting, yet most controversial eras in the history of the church. The movement started at the Council of Clermont on 27 November 1095, when Pope Urban II called on Christians to liberate the Holy Land ${ }^{2}$ from a Muslim ${ }^{3}$ hoard (Mastnak 2002:115; Murray 2006:xxxi).

Concerning the impact and global relevance of the Crusades, it is not surprising that the historical revision of these events is still developing. This could be linked to the fact that the term 'Crusades' is still used in popular discourse, often with a loaded and emotional connotation. The references to the Crusades by high-profile people like the pope who 'asked forgiveness' for the Boudreaux (2000) and former US president Obama (2015) who referred to the 'terrible deeds' done in the name of Christ during the Crusades also ensure that the term and the historical events are still part of current discourse and debates.

On the positive side, the term 'Crusades' is being used in novels, movies, the names of sport teams and even the names of restaurants. The term is also used to refer to anything from an evangelical campaign to the fight against hunger, poverty or other worthy causes. And this term also appears in the rhetoric of politicians.

\footnotetext{
1.The term 'Crusade' only came into use during the 17th century (cf. Lock 2006:258).

2.Several prominent Muslim leaders such as Osama bin Laden, Saddam Hussein and Muammar Gaddafi have referred to their western enemies as 'crusaders' (Bull 2005:122-123).

3.The term 'Muslim' was not used in the Middle Ages; the followers of Islam were commonly referred to as 'Saracens' by Christians
} (Mastnak 2002:103). 
This research is limited to describing the changes in attitudes towards the Crusades over the past five centuries.

\section{Background The rise of Islam}

Although Islam was not the only reason for the Crusades, one might argue that without Islam there would have been no Crusades. The attack of Muhammad (Mahomat) and his army on Mecca in $630 \mathrm{CE}$ eventually led to the whole of western Arabia becoming a Muslim community, called ummah (cf. Armstrong 2002:23; Chrisp 1991:10). During the 7th century, the Arabs (Muslims) captured three of the five Christian centres - Jerusalem, Antioch and Alexandria (Severy 1983:736). The threat to Christian countries increased over the centuries that followed, and even Rome was raided in 846 by Muslim forces (Partner 1998:57).

During the 8th century, Muslim rulers banned all displays of the cross in Jerusalem and increased the penalty tax (jizya) on Christians. In 772, the Muslim caliph ordered the hands of all Christians and Jews in Jerusalem to be branded. Plundering and destruction of church buildings in Jerusalem also occurred during the 10th and 11th centuries (Pruitt 2013:119, $126,128)$.

Because the Latin West's knowledge about the Muslims was basically non-existent (Lock 2006:308), the church prohibited Christians to conclude contracts with Muslims, making it impossible to make truce or peace with them (Mastnak 2002:125). Muslims were seen as inconvertible, and extermination was an acceptable solution; they were considered to have no freedom of choice and could therefore not choose between conversion and death; they were not even considered to have the right to defend themselves when faced with extermination (Mastnak 2002:125).

Pope Urban II characterised Muslims as 'subhuman and ravishers of women, murderers of Christians and polluters of Christian churches, violent, rapacious and aggressive' (Lock 2006:308).

\section{The world of the 11th century}

During the 11th century the church held the view that 'pagans are wrong and the Christians are right' (Mastnak 2002:125). The opponents of the crusaders were referred to as 'infidels', 'gentiles', 'enemies of Christ/God' and, above all, 'pagans' (Nicholson 2005:228).

By the time of the First Crusade at the end of the 11th century, Europe and the Middle East could be divided into three power blocks (Bartlett 2005:6): At the eastern extreme was the world of Islam; in the west, bordering the Atlantic, were the feudal states of western Europe; and between the two, at the centre of the world, was Byzantium.

Europe was emerging from the Dark Ages, and many of its nations were newly formed (Bartlett 2005:6, 8). This was also a time of immense religious change in western Europe, producing a renaissance in monastic institutions, and in general 'an intense religious feeling' (Bartlett 2005:8). Western Europe was economically very far behind the rest of the civilised world, while Byzantium and the Islamic states shared a flourishing commercial system (Tyerman 2006:2). Cities like Constantinople, Baghdad and Cairo boasted populations of hundreds of thousands, while the largest European cities like Rome, Venice and Milan only managed between 30 to 40 thousand (cf. Tyerman 2006:2).

From the 8th century onward western society was dominated by the church and no longer by the secular state as was the case during the early centuries of Christianity (Van Wijk \& Spies 1985:72). In every aspect of western life, the importance of the church was evident. Even at the courts of the Germanic kings, the bishops had replaced the curiales (the leading members of clans in Rome) and Roman bureaucrats (Van Wijk \& Spies 1985:72).

This society was divided into three classes: the clergy, the lords and the laity (Bartlett 2005:10). Frictions within this hierarchy helped shape the environment within which the Crusades evolved (Bartlett 2005:10). This eventually led to the development of the 'peace movements', which attempted to impose the 'Peace of God' on the world (Bartlett 2005:10), but unknowingly prepared the western society for the Crusades.

In addition to the peace movements, two other prominent features in the ideology of Western Europe should be considered as crucial in shaping western thought, making it more susceptible to the idea of war in God's Name: the concepts of pilgrimage and holy war.

\section{Pilgrimage}

At first the Roman authorities did not encourage voyages to Palestine. However, with the triumph of the cross at the time of Constantine, the practice of pilgrimage grew (Runciman 1980:21). Constantine's mother, Helena, who went to Palestine 'to uncover Calvary and to find all the relics of the Passion' (Runciman 1980:21), attributed greatly to the interest in pilgrimages to Jerusalem with her archaeological finds in Palestine.

Runciman (1980:24) considers the 10th century to be the beginning of the great age of pilgrimage. In Palestine the Muslim authorities seldom caused problems for travellers, but rather welcomed them because of the wealth they brought into the area (Runciman 1980:25). From the middle of the 11th century, however, pilgrims faced growing opposition from the Muslim authorities (Runciman 1980:31). The last two decades of the 11th century became increasingly difficult for pilgrims travelling to Palestine because the Turks controlled the whole of Asia Minor by 1080 and were attempting to enlarge their territory (Runciman 1980:40). The violence and warfare flowing from this situation caused the area to become unstable and dangerous for travellers (Runciman 1980:40). 


\section{Holy War}

Riley-Smith (2008:14) defines 'holy war' as 'being considered to be authorized directly or indirectly by God (or Christ) and as being fought to further what are believed to be his intentions'. He considers the Crusades as 'particularly theatrical manifestations' of holy war (Riley-Smith 2008:14). Holy war in the Christian tradition had its roots partly in the Old Testament:

Those wars in the service of God, carrying out the punishment of God - the collective warlike fury that, in its mystical aspects, was more terrible and impressive than the individual heroism of German and Nordic epics - had significant bearing on the medieval practice of war. (Mastnak 2002:61)

According to Mastnak (2002:61), the other source of legitimation for holy war was the Roman influence on Christianity. The Roman tradition and codification of wars against barbarians, seen as enemies of mankind, eventually became a model for Christian hostility towards pagans, heretics and the like.

\section{The Crusades ${ }^{5}$}

The idea of the Crusades originated in the thinking of the Latin West. The First Crusade was a combination of pilgrimage, penance and holy war, completely foreign to the thinking of the Christians in Byzantium who considered defensive wars necessary but regrettable (Lock 2006:299).

According to Madden (2002:71), no Crusade would be possible without the 11th-century 'revolution in Church thinking' concerning violence. It was during this century that holy war became part of the papal programme (Tyerman 2006:47). During the 11th century, the church's policy resulted in the directing of aggression towards non-Christian enemies (Bartlett 2005:11).

The reasons behind initiating the Crusades were quite complex. The Muslim expansion was one of the deciding reasons (Murray 2006:xliii regards it as the main reason), as the Seljuk Turks conquered Palestine, Syria and Anatolia during the 11th century, placing them within striking distance of Constantinople (Tyerman 2006:11-12). This imminent threat on the Byzantine Empire prompted the emperor, Alexius Comnenus, to appeal to Pope Urban II (in Western Europe) for military assistance (Bartlett 2005:5). Alexius focused on the one common factor that bridged the gap between Western Europe and the Byzantine Empire - the

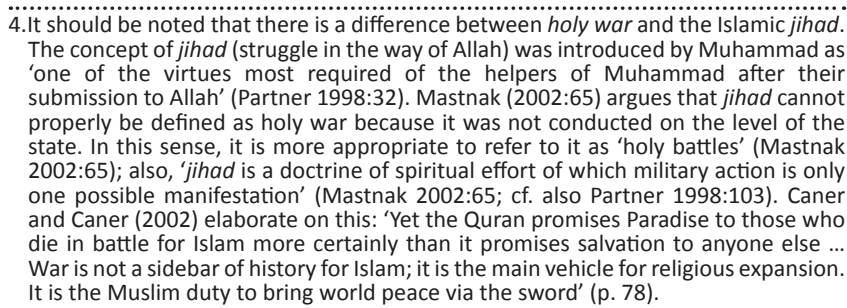
The concept of jihad (struggle in the way of Allah) was introduced by Muhammad as 'one of the virtues most required of the helpers of Muhammad after thei submission to Allah' (Partner 1998:32). Mastnak (2002:65) argues that jihad cannot properly be defined as holy war because it was not conducted on the level of the state. In this sense, it is more appropriate to refer to it as 'holy battles' (Mastnak 2002:65); also, 'jihad is a doctrine of spiritual effort of which military action is only one possible manifestation' (Mastnak 2002:65; cf. also Partner 1998:103). Cane and Caner (2002) elaborate on this: 'Yet the Quran promises Paradise to those who die in battle for Islam more certainly than it promises salvation to anyone else War is not a sidebar of history for Islam; it is the main vehicle for religious expansion. It is the Muslim duty to bring world peace via the sword' (p. 78)

5.The number of Crusades varies between 4 and 9 , with almost any number in between. However, Murray (2006:xxxvii) has identified not less than 41 campaigns (!) between the 11th and 15th centuries that can be classified as Crusades, with only five official Crusades.
Christian religion. Alexius' appeal to the West unleashed a 'tidal wave of humanity [that] was about to sweep into the Middle East' (Bartlett 2005:5). A few months later (November 1095), Pope Urban II delivered his famous sermon at Clermont, which effectively set the crusading movement in motion. The papacy benefited greatly from Urban's successful call to arms as it would contribute a great deal in reconciling Christianity between East and West and reunifying the church (Bartlett 2005:27-28).

Across Europe the cross was adopted as 'national symbol, banner or uniform' (Tyerman 2006:908). During the 15th century, the Crusades were referred to as 'the public business of Christendom' (Tyerman 1998:85).

The growing role of secular government in organising and implementing the Crusades led to what is termed by some historians as 'national crusading', which means that crusading began to serve 'worldly ambition' and 'national interests' (Mastnak 2002:257). National wars were now also portrayed as 'of equal worth as crusading, as holy wars in their own right, independent of the Holy Land tradition' (Tyerman 2006:911). In England, liturgy and practices like church processions and prayers, formerly devoted to the recovery of the Holy Land, were now directed to the support of royal wars. During the 1340s those in service of the royal wars also received privileges very similar to those granted to Holy Land crusaders, like 'essoin of court, exemption from taxation, moratorium on debt and pardon for crimes' (Tyerman 2006:911).

Although crusading had crossed over into the secular sphere, it was still held in high regard in society (Mastnak 2002:259). However, secular government's involvement led to crusading becoming more 'territorially centred', meaning that individual countries, like France, could independently arrange a Crusade (Madden 2002:4).

The pope theoretically retained the right of final authorisation of a Crusade, but this meant little in light of his sudden weakening of power (Mastnak 2002:260). By the 17th century the pope's influence had deteriorated to such an extent that he 'could no longer effectively participate in the political affairs of western Europe' (Cragg 1990:9). The emergence and rapid growth of nationalism in the preceding centuries contributed to the weakening of the pope's power (Pillay \& Hofmeyr 1991:129).

While the selling of indulgences strengthened the flow of money to the church coffers, it also 'opened the door for very serious abuse' and highlighted the 'spiritual bankruptcy of the Church' (Pillay \& Hofmeyr 1991:130). The stage had been set for the Reformation to sweep across Europe.

\section{Scholarly thoughts on the Crusades from the 16th century onwards}

The literature of the five consecutive centuries, starting with the 16th century, will be discussed next. It is clear that the 
historians mostly commented according to the worldviews of the specific timeframes they were living in, and also in accordance with their own interests.

\section{The 16th century}

During the 16th century historians distanced themselves from the 'age of certainty' (Tyerman 1998:109). Conditions in Europe were 'favourable for far-reaching religious changes' (Van Wijk \& Spies 1985:302), as this was the century that saw the birth of the Reformation (Dowley 1988:360), which in its own unique way contributed to new perspectives on the Crusades.

In addition, the fall of Constantinople in 1453 signalled the end of the Byzantine Empire (Lock 2006:133). Western Europe, and particularly Italy, was flooded 'with scholars whose views were different from those that had become common in the West' (Gonzalez 1985:7). Apart from the new philosophical outlooks, these scholars also placed the spotlight on changes that had taken place in the copying of ancient texts (Gonzalez 1985:7). Comparisons were made between the Greek text of the New Testament and the Latin Vulgate as Greek became more commonly known among western scholars. All of these factors contributed to return to the sources of the Christian faith, resulting in a reformation of doctrine and practice (Gonzalez 1985:7).

\section{The 16th century started the:}

debate between regarding the crusades as symbols of medieval superstition, barbarity and decadence or, alternatively, as a source of pride and witness to laudable Christian idealism and heroism had begun, fuelled largely by the contrast between academic dissection and popular invention. (Tyerman 2011:50)

William Shakespeare (1564-1616) wrote plays like Henry IV (Shakespeare [1597] 2012) and Othello, in which he immortalised the Ottoman Empire (Shakespeare [1603] 2012). Torquato Tasso (1544-1595), an Italian poet, retold the narrative of the First Crusade in the form of a romantic tale depicting the chivalry and love of those involved in the Crusade (cf. Tasso 1581:5-7). The Englishman, Francis Bacon (1561-1626), on the other hand, approached the topic with a philosophical seriousness, publishing all his works in Latin (collected in 1860 by James Spedding). His aim was to investigate the views of all the people involved in the Crusades, in the form of a dialogue (Bacon [1629] 1963). Bacon's work highlighted the shift in the opinion regarding the Crusades - a shift from faith to prudence, and from religion to law (cf. Tyerman 1998:109), which is very clear from his uncompleted work, Advertisement Touching an Holy Warre (1629). He (Bacon [1629] 1963:1-36) only justified offensive religious wars if they were supported by law. In 1584 the German scholar Matthew Dresser (1536-1607), a humanist and Lutheran, added his historical commentary to the Chronicon Hierosolymitanum of Reiner Reineck that was published in the same year (Reineck 1584). His commentary depicted how the Holy Wars (the standard academic description of the Crusades at the time) were scarred by papal lust for terrestrial power (Reineck 1584:17-40). He contrasted the greed and deceit of the papacy with that of the honest and pious crusaders, suggesting that the crusaders were ignorant and misled rather than mischievous, and stating that the Crusades 'had a double cause: one by the Roman popes, the other by Christian soldiers' (Tyerman 2011:42).

\section{The 17th century}

This century introduced 'modern' Church History. By the 17th century the expansion of the Ottoman Empire had stopped, and although the Turks still remained powerful, the threat was not severe (cf. Madden 2002:3). 'This allowed Europeans to take a step back and view the crusades more as a historical phenomenon than an ongoing campaign' (Madden 2002:3). Traditional crusading stopped being an active part of the 'World's Debate' between Byzantium and Islam (Gibbon 1906:56; cf. Sanutus 1611:vii, xii, 277). The Crusades were now specifically criticised on religious grounds (cf. Tyerman 2011:6). The work of Gibbon, though more polemic than historical, served his academic successors for the next two centuries on the discussion of the Crusades (cf. Tyerman 2011:86-87). The French scholar Jacques Bongars (1554-1612) was 'one of the greatest editors of crusade texts' (Tyerman 1998:107). He opted for religious, intellectual and moral disapproval of the Crusades, balanced with admiration for national rather than religious pride (cf. Tyerman 1998:110). In 1611, Bongars managed to compile (for the first time) all the major western sources for the First Crusade in his work Gesta Dei per Francos [God's Work through the Franks]. This was such a majestic work that historians used it as a reference until the 19th century - even Gibbon had a copy of this book (Keynes 1940:133). Bongars described Holy War as simultaneously a periculosissimis ita gloriosissimis expeditionibus [most dangerous and most glorious expedition] [Bongars 1611:vol. 1 (Dedicatory Preface):34]. In his highly critical book, The Historie of the Holy Warre (1639) - the first English publication that was a full investigation of the Crusades (cf. Tyerman 2011:60) - the English churchman and historian Thomas Fuller (1608-1661) referred to his work as a correction to the romanticism of Tasso (Fuller [1639] 1840:18). He regarded Islam as a senseless religion (Fuller 1639 [1840]:8) and the Crusades as a tragedy and a wasteful enterprise filled with wickedness and treachery (Fuller [1639] 1840:292, 179 , 186), while accusing the papacy of spilling blood unnecessarily and being arrogant (Fuller [1639] 1840:249$251,263)$. The fact that he acknowledged the danger of the Turks (Fuller [1639] 1840:9-10,17) as well as the role of the Catholic powers in protecting Protestant countries added much impact to his criticism of the Crusades (Fuller [1639] 1840:179, 186). He commented the following about the end of the Crusades: '[F]or continuance the longest, for money spent the costliest, for bloodshed the cruellest, for pretences the most pious, for true intent the most politic the world ever saw' (Fuller [1639] 1840:241). Tyerman (2011:63) regarded the work of Fuller as a 'portmanteau of early modern scholarship'. 
Louis Maimbourg (1610-1686) aired a completely different view on the Crusades. He was a French church historian and a Jesuit (Ellenblum 2007:8), who strongly opposed Protestantism, and whose works, although well written, had a 'clear partisan agenda that did not always respect the facts' (Lock 2006:280). Maimbourg wrote his masterpiece, the Histoire des croisades pour la delivrance de la terre sainte (History of the Crusades for the Deliverance of the Holy Land), for noble patrons in 1675, a work that was drenched with national and royal bias (cf. Ellenblum 2007:8; Tyerman 1998:110).

\section{The 18th century}

By the 18th century, the military might of the Ottoman Empire had been broken and the tables were turned as Europeans expanded globally (Madden 2002:3). The Enlightenment with its emphasis on rational thought, religious toleration and anti-clericalism provided an intellectual atmosphere in which the medieval Crusades were criticised on moral, religious and cultural grounds (cf. Madden 2002:4; Tyerman 2011:3-4).

Prominent historians such as Voltaire and Gibbon regarded the Middle Ages as a 'fetid pool of ignorance, superstition and fanaticism that stood between them and the glories of antiquity' (Madden 2002:4). Voltaire (Francois-Marie Arouet1694-1778), the French philosopher, was an enemy of all forms of fanaticism (Bull 2005:17; Gonzalez 1985:192), whose influence encouraged a complete denial of God (Cragg 1990:239). He was of the opinion that the Crusades were wasteful and pointless (Voltaire [1751] 1835:570; 552-561). He argued that the Latin kingdom came to a fall because of weak leadership and they were 'a band of corrupt and ignorant criminals' (Voltaire [1751] 1835:570). He also referred to the popes who 'opened' to the crusaders 'the gates of heaven, only imposing on them as a penance, the gratification of their predominant passion for plunder' (Voltaire 1759:349), and to the crusaders' 'thirst of plunder' (Voltaire 1759:350). ${ }^{6}$ The English historian Edward Gibbon ${ }^{7}$ (1737-1794) wrote the History of the Decline and Fall of the Roman Empire (1776-1788), in which he supported Voltaire (Gibbon 1906:27-49, 379-435). It comes as no surprise then that Gibbon described the Crusades negatively as the 'grossest barbarism' (Gibbon 1906:206). As Gibbon's approach to religion was more confessional than institutional, Tyerman (2011:85) regarded him as 'one of the inventors of serious ecclesiastical history'.

Added to these exponents are Hume and Diderot. David Hume (1711-1776) 'demolished the cherished certainties of his age with elegant simplicity' (Cragg 1990:167) and was influenced by Voltaire and Diderot (cf. Tyerman 2011:81). As far as the Crusades are concerned, Hume famously referred to them as the most signal and most durable

6.Voltaire, however, also referred to the people of Mahomat (i.e. Islam) in the same way: 'Especially we may observe a remarkable conformity between the manners of
his [Mahomat's] people, and those of the ancient Hebrews (I speak here of their his [Mahomat's] people, and those of the ancient Hebrews (I speak here of their
manners only) the same ardour to rush into battle in the name of the Lord, the same manners only) the same ardour to rush into battle in the name of the Lord,
thirst for plunder, the same division of the spoils ...' (Voltaire 1759:49)

7.In the preface to the book of Gibbon, the editor (unknown) states that this work of Gibbon acted mostly as the standard work for writers to reflect on the Crusade (Gibbon 1906:7). monument of human folly that has yet appeared in any age or nation' (Hume 1778:234). The French philosopher Denis Diderot (1713-1784) - just like Gibbon - based his work partly on that of Voltaire (Lock 2006:259; cf. Ellenblum 2007:7). He referred to the Crusades as a quest for a 'piece of rock not worth a single drop of blood' (Diderot 1875:vol. 14, $496,511)$.

Leaders of the Enlightenment remained firmly opposed to the Crusades in more or less the same way the Reformed Churches did. The French philosopher Jean Jacques Rousseau (1712-1778), for instance, took a strong stance against the Crusades, calling it a pagan phenomenon, stating:

I shall be told that Christian troops are excellent. I deny it. Show me an instance. For my part, I know of no Christian troops. Without disputing the valour of the Crusaders, I answer that, so far from being Christians, they were the priests' soldiery, citizens of the church. They fought for their spiritual country, which the church had, somehow or other, made temporal. Well understood, this goes back to paganism: as the Gospel sets up no national religion, a holy war is impossible among Christians. (Rousseau [1762] 1998:110)

Rousseau was against holy war and not war in itself. He argued that the Crusades were an example of trickery that had turned civic duty to the service of priestly interest (Rousseau [1762] 1998:106). War could be seen as a civic duty, but no war could be holy.

\section{The 19th century}

While preceding centuries introduced themes of national pride and religious or rational disapproval, the 19th century added the 'cultural progress and political ascent' (Tyerman 1998:113) on the historical perspectives of the Crusades. This century also introduced a mixture of emotion and reason with the rise of romanticism, nationalism, imperialism, colonialism, liberalism, socialism and racism (Tyerman 1998:114, 2011:5). Nationalism changed the view on the Crusades, especially among the French, 'who began to see the movement as an important part of their national heritage' (Madden 2002:4). It therefore comes as no surprise that, during the second half of this century and the beginning of the next century (1841-1906), the Académie des inscriptions et belles-lettres compiled and edited a vast collection of Crusade sources, called the Recueil des historiens des croisades [Collection of the Historians of the Crusades] in France (cf. Madden 2002:4).

Romantic images of chivalric crusaders marching to a foreign land to fight the enemy became popular, especially in Victorian England 'where the idea of fighting in faraway lands for ostensibly noble goals was a familiar one' (Madden 2002:4). This romantic nostalgia mixed with the supremacist ideology of the time produced unexpected, bizarre and sinister results as 'crusading became popularly admired' (Tyerman 1998:117). While crusading was formerly regarded as a 'disreputable example of excess', it became 'synonymous with fighting good causes, primarily religious or moral, 
throughout the western world, including North America' (Tyerman 1998:117). Exponents of this era are Michaud, Wilken, Mills, Scott, Von Sybel and Röhricht.

The French royalist and historian Joseph-François Michaud (1767-1839), who supported the monarchy during the French Revolution, recorded the religious motivation of the First crusaders, emphasising how important their actions were in defining the western Christendom (Michaud 1852:vol. 1, 1-328). He published the six volumes of his Histoire des Croisades [History of the Crusades] in Paris between 1817 and 1822, using Bongars and Tasso as primary sources (Tyerman 2011:109). He considered the Crusades to be a time of revolution, the consequence of a time of 'confusion and decadence that favoured the invasion of new ideas, especially when those ideas appear supported by the sword' (Michaud 1852:vol. 1, 7). He believed that the Crusades 'constituted nothing less than a vast and mysterious enterprise which had as its goal the conquest and civilisation of Asia' (Michaud 1852:vol. 4, 344). He used the term 'heroic' abundantly, referring to the 'heroic resignation' of the 'early soldiers of the cross' (Michaud 1852:vol. 1, xx, 409), their 'heroic bravery' (Michaud 1852:vol. 1, xxvi; 180), stating that 'something heroical and generous was mingled with the barbarous manners of the Franks' (Michaud 1852:vol. 1, 37). He defended the material consequences of the Crusades in line with the popular opinion of the time, namely, that the holy wars had as their goal the conquest and civilisation of Asia, and as such the crusaders established Christian 'colonies' (Michaud 1852:vol. 1, 38). According to Tyerman (2011:100), Michaud's work 'secured its lasting significance: a contemporary agenda wrapped up in the concept of "la France en Orient"; and throughout a unifying concern with what he called "le monde moral"' (cf. Michaud, vol. 1:374, vol. 2:172; vol. 3:297, vol. 4:202-203, 206).

Friedrich Wilken (1777-1840), a German historian, wrote seven volumes on the Geschichte der Kreuzzüge nach morgenländischen und abendländischen Berichten. Tyerman (2011:129) called him the first 'professional' historian to capture the Crusades in book form. In drawing a comparison between the work of Michaud and Wilken, Lock (2006:261) argued that 'both attempted to evaluate the evidence at their disposal in an impartial light; but both provided a model for Christian West versus the Islamic East, centred the Crusades firmly on the Holy Land and, incidentally, opened the rivalry between French and German historical scholarship in the nineteenth century'. This is then also the reason why the first volume of Wilken's work is called Die Gründung des Königreichs Jerusalem (The Founding of the Kingdom of Jerusalem Wilken 1807-1832:vol. 1). Wilken's work is seen as the more judicious of the two, specifically in the use of his source material and the fact that he was the first to use Arabic sources. While Michaud's work became the more popular study (Lock 2006:261), Wilken's work became the text book for the rest of the 19th century (Tyerman 2011:130-131).

The popularity of The History of the Crusades written by Charles Mills (1788-1826) in 1820 is evident from the fact that it is to be found in 'most bibliographies or footnotes of 19th century histories of the crusades' (Siberry 2000:14). Mills, an English barrister and historian, abandoned the law to concentrate on his historical writing as a critique against Edward Gibbon. He maintained that Gibbon's work was aimed at the destruction of Christianity, and criticises Gibbon on the following points:

- Gibbon did not portray the 'holy wars' well enough, but relied on works of Vertot (1772) and Mailly (1780), which Mills finds insufficient (Mills 1820:vii).

- Gibbon neglected to mention the fourth, sixth and seventh Crusades and put far too much emphasis on the 'expedition, in which the Byzantine Empire was principally interested' (Mills 1820:viii).

- After a lengthy exposition of Saint Bernard (a Scotchman), the chaplain of the Bishop of Puy (Mills 1820:220), who later became the patriarch and was very much involved with the Second Crusade, Mills criticised Voltaire and Gibbon who were negative towards Bernard, saying that he 'was induced by envy of a rival monk' (Mills 1820:373).

- He referred to the writings (Gesta Dei per Francos 1611) of the French scholar Jacques Bongars ('Bongarsius') as a 'noble collection', while Gibbon supported Jortin who called it the Gesta Diaboli per Francos (Mills 1820:461).

Mills condemned the Crusades for its cruelty and intolerance while at the same time having sympathy with the crusaders whom he referred to as the deluded fanatic and noble adventurer in arms' (Mills 1820:373, 374). He was sceptic about the role of the Roman Catholic Church and its pontiffs in the Crusades:

It was the policy of the Church of Rome to encourage the spirit of crusading, because they who skilfully administer to public prejudices, become in time masters of the people. (Mills 1820:284)

The pontiffs were enriched by Crusade contributions and 'broke the spirit of crusading' (Mills 1820:285). Despite his sympathy towards devoted crusaders, he felt that the Crusades themselves changed the face of war as well as religion: 'Religion lost its mildness and charity; and war its mitigating qualities of honour and courtesy. Such were the bitter fruits of the holy wars' (Mills 1820:373). He concluded: 'We feel no sorrow at the final doom of the Crusades, because in its origin the war was iniquitous and unjust' (Mills 1820:375).

The novelist Sir Walter Scott (1771-1832) is considered to be 'one of the most influential figures in the creation of the popular image of the Middle Ages and the Crusades themselves' (Siberry 2000:112; cf. Tyerman 1998:114). He wrote two historical novels on the Crusades, called The Betrothed and The Talisman, which were published in 1825 as a compendium called Tales of the Crusaders. Although he admired chivalry and gallantry, he was antagonistic towards the Crusades (cf. Tyerman 1998:114). By means of storytelling, this novelist portrayed the influence of the Crusades on the people partaking in it. In his antagonism, he uses the terms 'Crusade/s' and 'crusader/s' very sparingly in both his 
novels, stating, for example, that the crusaders left their own countries defenceless while on Crusade (Scott 1825:2).

Heinrich Karl Ludolf Von Sybel (1817-1895), a German historian, made profound inroads into crusading history by applying source criticism to the First and Second Crusades (Lock 2006:285). His Geschichte des ersten Kreuzzugs (History of the First Crusade - 1841) proved to be a milestone in Crusade historiography (Siberry 2000:9). In a translation of his book, Lady Duff Gordon also added his lectures delivered at Munich. In the first lecture, Von Sybil argued:

The subject of these pages, that series of great wars which we designate as the Crusades, is one of the greatest revolutions that has ever taken place in the history of the human race. (Gordon 1861:1)

In the first part of his book (three chapters), titled Zur Kritik der Quellen und der Literatur [Critique on the Sources and Literature], Von Sybel criticised his predecessors as follows: After noting Fuller to be the first to justify the Crusades, and giving Wilken some respect (as well as criticism), he called Maimbourg a mere snob, Voltaire a weak researcher, Michaud a very inferior researcher of primary sources, while Tasso used unhistorical material and Mills (a contemporary) was lacking critical method (Von Sybel 1841:1-142; cf. Gordon 332-345; 353-356).

As a German teacher and Crusade historian, Reinhold Röhricht (1842-1905) wrote overview histories of the Crusades as well as studies of individual Crusades, focusing his attention on the golden age of crusading in the 13th century, and dedicating the first part of his book to Die Kreuzfahrt des Kaisers Friedrich II (1228-1229) (The Crusade of Emperor Frederick 2) (Röhricht 1874:1-112). He innovatively made use of pilgrim texts and geographical material, and his edition of the charters of the Latin Kingdom of Jerusalem (still in use and reprinted in modern times) set high technical standards (cf. Lock 2006:284). Lock gave Röhricht the title of 'father of modern crusade studies'.

\section{The 20th century}

As Crusade historiography belonged to the French and the German writers during the 19th century, the prominent Crusade historians during the 20th century were American, British and Israeli scholars (cf. Lock 2006:269). The views of five exponents are discussed here: Grousset, Prawer and Setton, with the two most influential writers Erdmann and Runciman.

The French historian René Grousset (1885-1952) is best known for his work Histoire des Croisades (3 Vols, 1934-1936), in which he focused on the Crusades in the Holy Land, placing it 'within a model of French colonial expansion', a step that sparked a debate on the 'very existence and nature of medieval colonialism' (Lock 2006:269). This work of Grousset contains the lengthiest exposition of the concept of ‘French colonies' (cf. Tyerman 1998:122).
Joshua Prawer (1917-1990) is considered to be the 'founder and inspirer of Israeli crusading studies' (Lock 2006:282), and in recognition of his groundbreaking work, comprising his book, The Latin Kingdom of Jerusalem: European Colonialism in the Middle Ages, a street in Jerusalem, leading to the remains of a crusader village, was named after him in 1999. Prawer was one of several modern Israeli scholars who still believed that 'it is justified to regard the Crusader kingdom as the first European colonial society' (Prawer 1972:469). In addition to the colonial aspect of the Crusades, Prawer also considered the Latin rule of the Crusaders as 'non integration, or more exactly Apartheid' (Prawer 1972:524).

The American historian Kenneth Meyer Setton (1914-2000) was the general editor of A History of the Crusades (6 Vols, 1955-1989), a project in which he oversaw the work of more than 60 specialists. This work of Setton, also known as The Wisconsin History or The Pennsylvania History, ranked as being monumental by 20th-century standards (cf. Lock 2006:269). Setton (1969:xxi) recognised in the First Crusade the convergence of two lines of Christian development, namely pilgrimage and holy war. The concept of pilgrimage was well established by the time of the First Crusade, being 'nearly as old as Christianity', but the idea of holy war against the infidels (faithless Muslims) was a later 'distinctively western development' (Setton 1969:xxi, cf. 1985).

In 1935 Carl Erdmann (1898-1945) wrote Die Entstehung des Kreuzzugsgedankens [The Origins of the Idea of Crusading]. This is a detailed monograph focusing on the pacifist church becoming a militant church during the 11th century. He regarded the Crusades as the culmination of processes that have already started during the times of the Church Fathers. However, until the 11th century only defensive warfare was allowed, which changed with the introduction of the Crusades. He also investigated the nature as well as the origins of the Crusades.

Sir Steven (James Cochran Stevenson) Runciman (1903-2000) wrote many works, one among them is the History of the Crusades (3 Vols, 1951-1954). According to Tyerman (2011:192193, 196), these three volumes 'represent the most astonishing literary phenomenon in crusade historiography since Michaud' as he regarded Runciman as the 'true heir of Michaud'. He added: 'This didacticism provides Runciman's History with its lasting immediacy ... Runciman's History is the last chronicle of the crusades' (Tyerman 2011:196). RileySmith (2008:66) concurred that Runciman wrote the 'most admired history in English' on the Crusades. Madden (2002:211) considered Runciman to be the 'best-known crusade historian in the world', and referred to his History of the Crusades as a 'compellingly written work that is still extraordinarily popular'. Runciman's point of departure was:

I believe that the supreme duty of the historian is to write history, that is to say, to attempt to record in one sweeping sequence the greater events and movements that have swayed the destinies of man. (Runciman 1951-1954:vol. 1, xiii) 
He was no friend of the Crusades and was outspoken on many a topic; for example, he called the destruction of the Byzantine civilization 'in the name of Christ ... the greatest tragedy of the Middle Ages ... The whole tale is one of faith and folly, courage and greed, hope and disillusion' (Runciman 1951-1954:vol. 1, xiii), and added: 'There never was a greater crime against humanity than the Fourth Crusade' (Runciman 1951-1954:vol. 3,130). Tyerman (2006:28) referred to Runciman's opinion on the Crusades as 'the most ringing modern verdict [that] has become justifiably famous'. His three volumes are saturated with literary device, creating imaginative scenes of actors and actions.

\section{Current attitudes towards the Crusades}

A few of the most recent exponents on Crusades - the late 20th and the early 21stcenturies - will now be discussed. This era is responsible for the most research conducted on the Crusades worldwide. The scholars on Crusades have gone so far as to found the International Society for the Study of the Crusades and the Latin East in 1980, with its own journal, Crusades (cf. Tyerman 2011:216). Proponents of this era are Bartlett, Lock, Madden, Mastnak, Partner, Tyerman, RileySmith, Asbridge and Bull.

Wayne Bartlett's book, The Crusades: An Illustrated History, comes across as a sound, straightforward, current account of the Crusades. From the Introduction, it is clear that the author is all too aware of the modern sensitivities surrounding the term 'Crusade' (Bartlett 2005:1). For him the greatest lesson of the Crusades is that 'intolerance breeds intolerance' (Bartlett 2005:278).

Peter Lock gives a thorough account of the Crusades in his book The Routledge Companion to the Crusades, although he addresses the term 'Crusade' in a modern, and not in a medieval sense (Lock 2006:289). While he discusses the development of thought on the Crusades, he does not explain why present-day attitudes have changed and are changing towards the Crusades. One interesting topic in his book relates 'what the west knew of Islam at the time of the Crusades, and vice versa' (Lock 2006:308).

Thomas Madden's book, The Crusades: The Essential Readings, is a compilation of works of several authors on the Crusades, focusing on the historical aspect of the movement. In his Introduction, he touches on the changing perspectives on the Crusades (Madden 2002:2, cf. 2004), discussing how, among others, nationalism, colonialism and racism changed the Crusade history (Madden 2002:4). He ends the section with a short discussion on how the $9 / 11$ attacks on the Twin Towers could affect the next generation's approach towards the Crusades (Madden 2002:7). He criticises scholars like Runciman, stating that modern historians disagree with him concerning the characterisation of the Crusades:

Recent scholarship has overturned the idea that medieval crusaders were motivated solely by a desire for plunder and conquests. New evidence and new interpretations have stressed religious motivations ... most crusaders were honestly attempting to perform a selfless act for the good of Christendom. (Madden 2002:6)

Tomaz Mastnak's book Crusading Peace: Christendom, the Muslim World and Western Political Order deals with the First Crusade, as well as some leading figures of the 12th and 13th centuries. His main concern and focus is the delicate balance between (holy) peace and (holy) war, with specific reference to the volatile relationship between Christian and Muslim. He discusses how initially there was 'holy peace' and that the church was averse to the shedding of blood, but during the 10th century this view changed (Mastnak 2002:16). Mastnak investigates the reasons behind the changing attitudes from peace to war, and the way that this has shaped the minds of the western world to the point that 'everyone, including the distinguished and angelic thinkers, mystics, all bent their heads and knees before the Crusading spirit' (Mastnak 2002:345).

Peter Partner's book God of Battles: Holy Wars of Christianity and Islam focuses on the concept of 'holy war', in particular on Christian and Muslim holy war. According to him, 'holy war magnified the role of a particular religious authority' (Partner 1998:113). He also has a significant discussion on the 18th-century Enlightenment, with specific reference to the Crusades (Partner 1998:276). Although the Enlightenment was more than two centuries ago, it has direct relevance to the current changing attitudes towards the Crusades.

Christopher Tyerman is a leading authority on the Crusades, arguing that this movement was 'perhaps the most familiar, if misunderstood, of all medieval phenomena' (Tyerman 2006:xv). In 1998 he already stated that 'modern disapproval, like past enthusiasm, is as much a product of our times as of the crusades' (Tyerman 1998:124). He narrates how holy war became part of the papal programme (Tyerman 2006:47), as well as the role religion played in Christian and Muslim wars (Tyerman 2006:54). In a radio interview that he had with National Public Radio in 2005, he stated that it is not correct to see the Crusades as a precursor of modern conflicts in the Near East - in itself it serves as a wake-up call for many people today. He confirms Madden's reasoning that the crusaders went to Palestine 'for essentially ideological religious reasons' and not for financial profit, as 'crusaders habitually made thumping losses' (Tyerman 2005). In their minds the crusaders were conducting a religious exercise through which they could 'gain spiritual merit and benefit' (Tyerman 2005). The main profits for those participating in the Crusades were the 'spiritual indulgence, the time off purgatory, the prospect of heaven and, of course, relics, which were important' (Tyerman 2005). The fact that the Crusades were considered to be holy wars by the Christian society at the time means that those who engaged in these wars were performing a holy act in itself, depicting the killing and fighting to be in accordance with God's will (Tyerman 2005). He closes by arguing that the Crusades are to be viewed as a 'very striking phenomenon of a very different sort of society in the Middle Ages', and as such the Crusades 'should not be discounted as a barbaric eccentricity' (Tyerman 
2005). His book The Debate on the Crusades, 1099-2010 (Tyerman 2011) provides several discussions on the changing thought of the western mind from the time of the Crusades till the first decade of the 21st century.

In his book, The Crusades, Christianity and Islam, Jonathan Riley-Smith reasons that the Crusades were 'not thoughtless explosions of barbarism' but 'considered to be theologically justifiable by a society that felt itself to be threatened' (RileySmith 2008:79). He defends the Crusades by arguing that it is difficult to understand 'the intensity of the attachment felt for the holy places in Jerusalem, the concern aroused by heresy and physical assaults on the church, and the fear Westerners had of Muslim invaders' (Riley-Smith 2008:79). He adds that 'modern Western public opinion, Arab Nationalism, and Pan-Islamism all share perceptions of crusading that have more to do with 19th century European imperialism than with actuality' (Riley-Smith 2008:79). According to RileySmith (2008:76), the erroneous idea that the West is still engaged in crusading is very much alive in the Muslim minds and not only in that of extreme Islamists. With reference to possible apologies (whether real or perceived) by the Catholic Church and others ${ }^{8}$ regarding the Crusades, Riley-Smith (2008) points out that:

an apology for past events would have been futile as far as the Muslims are concerned, since crusading is for them still a reality, conducted in more sophisticated and effective ways than before. (p. 77)

In his book The First Crusade: A new History, Thomas Asbridge states that for most of the crusaders the 'booty' they received at the end of the Crusade consisted of religious relics, including a piece of the Holy Sepulchre, as well as an 'array of artefacts, including a single hair from Christ's beard, a whole ball of the Virgin Mary's hair, pieces of the True Cross and the Holy Lance and remnants of numerous saints' (Asbridge 2005:329).

Marcus Bull (2005), a student of Riley-Smith, wrote a book called Thinking Medieval: An Introduction to the Study of the Middle Ages in 2005, in which he states, concerning the difference in thinking between medieval and modern man:

The mindsets of the people who conceived, planned and went on crusades were fundamentally different from our own assumptions and values. They were not 'like us' only more thuggish and intolerant. (p. 5)

He is of the opinion that modern man needs to make 'mental adjustments' if they want to 'understand the crusaders and

\footnotetext{
8.This comment relates to two occasions where people had the conviction that Christians were apologising for the Crusades: (1) during the 1990s, a total of 2500 western Christians participated in the Reconciliation Walk, a three-year-and-fourmonth journey retracing 'the massacre trail of the Crusaders from Cologne Germany, through Turkey, Syria and Lebanon, turning it into a repentance route (Dixon 1999). They concluded their journey in Jerusalem 'to ask forgiveness for the historical bloodshed and for a lingering "crusader mentality" in the Church today" (Dixon 1999). (2) Boudreaux (2000) reported that, during the 2000 millennia celebrations, the late Pope John Paul II apologised for 'Catholic sins past and celebrations, the late post and present.' The pope begged God's forgiveness for sins committed or condoned by Roman Catholics over the last 2000 years, including sexism, racism, hatred of Jews and violence in defence of the Catholic faith (Boudreaux 2000). Based on this apology, many understood the pope's action as a "pardon' for the Crusades. However, Madden (2004) points out that the pope failed to apologise for the Crusades directly and merely 'asked forgiveness from all those that Christians had unjustly harmed'.
}

their world without importing anachronistic value judgements' (Bull 2005:131). Bull (2005) continues by stating that one of the biggest challenges in studying the Middle Ages:

is to unthink a raft of modern assumptions and values about the morality of violence, because only then is it possible to understand how people with entirely different approaches were able to function. (p. 131)

Bull (2005) argues that the Crusades were a demonstration of the 'complete alterity' of the Middle Ages, that is to say:

the notion that when we mentally project ourselves into the medieval past, what we will find is an alien environment in which the differences from our own experience impress themselves upon us far more than the similarities, which are likely to be superficial anyway. (p. 131)

According to Bull (2005:122-123), both the West and the Muslim world make use of Crusade rhetoric, and in the post-9/11 war of words' both sides are guilty of 'forcing historical continuity out of discontinuity'. He calls this the 'wormhole effect' - something that happens 'when a piece of the past ... is brought into immediate contact with a piece of the present ... without asking awkward questions about what happened in the interval between them' (Bull 2005:123). He adds that there is a difference between 'what actually happened in the past and what some people would like to have happened' (Bull 2005:131). Because so many in the modern world fail to see this difference, there is a 'current misappropriation of the crusades [which is] so rampant' (Bull 2005:131).

\section{An overview of the changing perspectives on the Crusades}

Having referred to some leading literature and exponents of the past five centuries, there is a clear change in perspective on the Crusades, a change that is in line with the trend of each century. The 16th century, which was at the same time the origin of the modern era and the pinnacle of the Renaissance, produced a more romantic, even entertaining view of the Crusades (with Shakespeare and Tasso), although some scholars discussed the more serious side of the Crusades (Bacon) or ventured to criticise it by means of a moral discourse (Dresser 1584) (cf. Ellenblum 2007:5-6).

During the early-modern 17th century, which introduced a renewed interest in the Bible and classical writers of Greece and Rome, the Crusades were viewed as a historical phenomenon. While Maimbourg's writings were drenched in a positive national and royal bias, scholars like Bongars not only continued the general (positive) view of the previous century but also balanced it in a rational way, stating that the Crusades were 'most dangerous and most glorious'. Contrary to that, writers like Fuller regarded the Crusades to be a tragedy. The shift from positive or positivistic to the rather negative side has started. 
The 18th-century Enlightenment, with its trend towards scientific thinking, provided an intellectual atmosphere with a gross negativity towards the Crusades. Writers like Voltaire ('the whole enterprise was wasteful and pointless; a desire for plunder'), Gibbon ('a bizarre manifestation of medieval barbarism'), Hume ('the most signal and most durable monument of human folly'), Diderot ('a quest for a piece of rock not worth a single drop of blood') and Rousseau ('a pagan phenomenon; an example of trickery') serve as good examples for this period. Most of these statements were made from a rationalistic point of view and were not based on actual research (cf. Tyerman 2011:78). The rationalism in the 18th century (with exponents like Voltaire and Rousseau) treated the Crusades in an essentially ironic way (cf. Partner 1998:276). On the one hand, they viewed the Crusades as barbaric, but on the other hand, it was seen as a vehicle with which a wider culture and more civilised manners were brought into Europe from the Muslim East (Partner 1998:276).

The 19th century served as mould for Romanticism and Idealism, with countries like Germany, France and England taking the lead. The rationality and logical thought of the Enlightenment were questioned, while the romantic nostalgia of the time led to the fact that the Crusades became popularly admired again. Although scholars like Mills and Scott still criticised the Crusades, the general feeling towards the Crusades was a positive one, with writers like Michaud (the most positive), Wilken, Von Sybel and Röhricht. Tyerman compliments Michaud by stating that 'nowhere did popular, academic and political enthusiasm combine so productively' (Tyerman 2011:141).

Modernism and postmodernism were the trends of the 20th century. From the middle of that century linguists started to concentrate on the meaning of texts, rather than just criticising the content thereof. Grousset, Prawer and Setton are examples of scholars who were more focused on the facts and information of the Crusades than on criticising the movement. However, Erdmann and Runciman still observed a negative stance towards the Crusades.

The current trend - starting during the late 20th century - in the study of the Crusades depicts less emotion and more information; scholars like Bartlett, Lock, Partner and Asbridge are good examples of this notion. Certain scholars, like Mastnak, seem to lean more towards an 'enlightened' approach, where the Crusades are regarded as more negative than positive. While the folly of the Crusades may be recognised by modern-day scholars, a more balanced and optimistic view concerning the Crusades is evident among scholars like Madden, Tyerman and Riley-Smith. A last exponent in the person of Bull investigated the different thought patterns portrayed by the people belonging to different eras, which are very important to take note of when doing research on an event like the Crusades.

By investigating the changes in attitude towards the Crusades from century to century, contrary to the expectation of the authors, every century 'boasts' with at least one influential author who was or is negative towards the Crusades, displaying a line of negativity despite the positive accounts.

\section{Conclusion}

Through the ages attitudes towards the Crusades have differed from each other, depending on the trend of each century - many exponents supported these so-called holy wars, while others rejected or criticised them. None of the present-day scholars condone the atrocities committed during the Crusades. Instead, they follow a balanced viewpoint, much in line with that of the previous century, in which they recognise the fact that the world and its people have changed a lot over the centuries. They maintain that it is difficult for modern Christians to identify themselves with their predecessors during the time of the Crusades. The idea that Christians would consider it their religious duty to slaughter people in God's Name is an alien concept in current times. Yet at the time of the Crusades everybody bent before the crusading spirit (cf. Mastnak 2002:345).

The religious zeal that inspired Christians to wage war in God's Name was common at the time of the Crusades. The threat of the Muslim onslaught, the culture of violence coinciding with the teaching of Holy War, as well as the power and influence of the church and the pope during the time of the Crusades were all contributing factors to the reality and execution of the Crusades. Considering the fact that joining in a Crusade would mean forgiveness of sins and access to heaven, the importance of religious reasons cannot be overemphasised.

If one were to determine blame for the atrocities of the Crusades, the bulk would be placed on the Roman Catholic Church and its popes during that time. While succeeding in enriching and empowering themselves as well as selling the lie of the forgiveness of sins for those joining a Crusade, the popes failed to impress basic human decency on the crusaders, resulting in the terrible atrocities committed by the crusaders - such as the slaughter of Jews and other Christians, as well as Muslims who surrendered in battle, to name but a few, which are the leading contributors to the notoriety of the Crusades in the mind of modern man. For present-day Christians, the Crusades are something of the past, although it still lives on in the mouths of unthinking politicians.

Of recent concern is the fact that the term 'Crusade' also lives on in the modern Muslim mind. Several prominent Muslim leaders of recent years have referred to their western enemies as 'crusaders'. Certain scholars suggest that the preoccupation of Muslims with the Crusades is relatively new: 'It was only in the twentieth century when the west had become more powerful and threatening, that Muslim historians would become preoccupied by the medieval Crusades' (Armstrong 2002:95). This shows that it is easy, yet irresponsible, to take the Crusades out of their historical context and force it into the present-day political agendas and rhetoric. In the Muslim world, this kind of propaganda 
has the ability to stir up emotions within the fanatic fringe where the idea of jihad is still adhered to. Resulting attacks on western ('Christian') targets trigger reprisals from the West. Conveniently, the Crusades are then made out to be the 'original scapegoat' behind the conflict between these forces. This scenario fits in perfectly with what Bull (2005:131) refers to as the 'current misappropriation of the Crusades'.

The nature of the changing attitudes towards the Crusades, just like the reasons behind them, is legion and complex. It reveals not only a changing attitude towards the Crusades but, in fact, a change in awareness about this movement. It seems that certain present-day struggles, along with their political agendas, propaganda and the like, have all succeeded in generating an awareness of the Crusades. Ideally, modern society should understand the Crusades within their historical context and not refer to them by any means in the process of addressing modern-day differences.

\section{Acknowledgements Competing interests}

The authors declare that they have no financial or personal relationships which may have inappropriately influenced them in writing this article.

\section{Authors' contributions}

J.T. and E.O. equally contributed to the research and writing of this article.

\section{References}

Armstrong, K., 2002, Islam: A short history, Modern Library, New York.

Asbridge, T., 2005, The First Crusade: A new history, The Free Press, London.

Bacon, F., 1629 [1963], 'Advertisement touching a Holy Warre', in G. Holzboog (ed.), The works of Francis Bacon, vol. 6, pp. 1-36, Friedrich Frommann Verlag, StuttgartBad Cannstatt.

Bartlett, W.B., 2005, The Crusades: An illustrated history, Sutton Publishing, Gloucestershire.

Bongars, J., 1611, Gesta Dei Per Francos, Sive Orientalium Expeditionum, et Regni Francorum Hierosolimitani Historia, 2 vols., Typis Wechelianis, Hanover.

Boudreaux, R., 2000, 'Pope apologizes for Catholic sins past and present', viewed 16 November 2016, from http://www.articles.latimes.com/2000/mar/13/ news $/ \mathrm{mn}-8338$

Bull, M., 2005, Thinking medieval: An introduction to the study of the middle ages, Palgrave Macmillan, Hampshire.

Caner, E.M. \& Caner, E.F., 2004, Christian Jihad: Two former Muslims look at the Crusades and killing in the Name of Christ, Kregel Publications, Grand Rapids, MI.

Chrisp, P., 1991, The rise of Islam, Wayland Publishers Limited, East Sussex.

Cragg, G.R., 1990, The church and the age of reason 1648-1789, Penguin Group, London.

Diderot, D., 1875 [2016], Oeuvres Complètes de Diderot, J. Claye, Paris.

Dixon, T., 1999, 'Jerusalem: Reconciliation walk reaches pinnacle', viewed 15 November 2016, from www.christianitytoday.com/ct/1999/september6/9ta024. html

Dowley, T. (ed.), 1988, Die Geskiedenis van die Christendom, Struik Christelike Boeke, Kaapstad.

Dresser, M., 1584, Chronicon Hierosolymitanum, Helmstedt.

Ellenblum, R., 2007, Crusader castles and modern histories, Cambridge University Press, Cambridge.

Erdmann, C., 1935, Die Entstehung des Kreuzzugsgedankens, Forschungen zur Kirchen- und Geistesgeschichte 6, Verlag W. Kohlhammer, Stuttgart.

Fuller, T., 1639 [1840], The Historie of the Holy Warre, William Pickering, London.

Gibbon, E., 1906, The history of the decline and fall of the Roman Empire, vol. VI, Methuen \& Co, London.
Gonzalez, J.L., 1985, The story of Christianity, Vol. 2: The reformation to the present day, Harper Collins, New York.

Gordon, D. (ed. \& transl.), 1861, The history and literature of the Crusades: From the German of Von Sybel, Chapman and Hall, London.

Grousset, R., 1934-1936, Histoire des Croisades, 3 vols., Perrin, Paris.

Gundani, P., 2004, 'Christian historiography and the Christian woman: A critical examination of the place of Felicity Walatta Pietros and Kimpa Vita in African Christian historiography', Studia Historiae Ecclesiasticae 30(1), 75-89.

Hume, D., 1778, The history of England from the invasion of Julius Caesar to the revolution in 1688, 6 vols., Liberty Fund 1983, Indianapolis, IN.

Keynes, G., 1940, The library of Edward Gibbon, Cape, London.

Lock, P., 2006, The Routledge companion to the Crusades, Routledge, New York.

Madden, T.F. (ed.), 2002, The Crusades: The essential readings, Blackwell Publishers Ltd., Oxford.

Madden, T.F., 2004, 'Interview: The Crusades', viewed 14 November 2016, from www. churchinhistory.org/pages/leaflets/the-crusaders.htm

Mailly, J.-B., 1780, L'Esprit des Croisades, 3 vols., Chez Moutard, Paris.

Maimbourg, L., 1675, Histoire des croisades pour la delivrance de la terre sainte, Sébastien Mabre-Cramoisy, Paris.

Mastnak, T., 2002, Crusading peace: Christendom, the Muslim world and western political order, University of California Press, Berkeley, CA.

Michaud, J.-F., 1852 [1817-1822], Histoire des Croisades, 6 vols., transl. W. Robson, Michaud's History of the Crusades, 3 vols., George Routledge and Co., London.

Mills, C., 1820, The history of the Crusades for the recovery and possession of the Holy Land, vol. 2, Longman, London.

Mommsen, H., 2009, 'Changing historical perspectives on the Nazi dictatorship', European Review 17(1), 73-80. https://doi.org/10.1017/S106279870900057X

Murray, A.V. (ed.), 2006, The Crusades: An Encyclopedia, ABC Clio, Santa Barbara, CA.

Nicholson, H. (ed.), 2005, Palgrave advances in the Crusades, Palgrave Macmillan, Hampshire.

Nytagodien, R.L. \& Neal, A.G., 2004, 'Confronting an ugly past', The journal of American Culture 27(4), 375-383. https://doi.org/10.1111/j.1542-734X.2004. American

Obama, B., 2015, 'Obama compares ISIS to the crusades, receives heavy backlash...', 05 February 2015, National Prayer Breakfast Speech, viewed 16 November 2016, from https://www.youtube.com/watch?v=ADYIKcWMzdo

Oliver, E., 2011, 'South Africa: The arduous task of facing our religious past', Acto Theologica 31(1), 72-94. https://doi.org/10.4314/actat.v31i1.5

Orwell, G., 1949, Nineteen eighty-four, Oceania, London.

Partner, P., 1998, God of battles: Holy wars of Christianity and Islam, Princeton University Press, Princeton, NJ.

Pillay, G.J. \& Hofmeyr, J.W. (eds.), 1991, Perspectives on church history: An introduction for South African readers, De Jager-HAUM Publishers, Pretoria.

Prawer, J., 1972, The Latin Kingdom of Jerusalem: European Colonialism in the middle ages, Weidenfeld and Nicolson, London.

Pruitt, J., 2013, 'Method in madness: Recontextualizing the destruction of churches in the Fatimid era', Muqarnas: An Annual on the Visual Cultures of the Islamic World 30, 119-139.

Reineck, R. (ed.), 1584, Chronicon Hierosolymitanum, Jacobus Lucius, Wolfgang Richter, Helmstadt, Frankfurt.

Riley-Smith, J., 2008, The Crusades, Christianity and Islam, Columbia University Press, New York.

Röhricht, G.R., 1874, Beiträge zur Geschichte der Kreuzzüge, Weidmannsche Buchhandlung, Berlin.

Rousseau. J.J., 1762 [1998], The social contract or principles of political right, transl. H.J. Tozer, Wordsworth Classics of World Literature, Hertfordshire.

Runciman, J.C.S., 1951-1954, A history of the Crusades, 3 vols., Cambridge University Press, Cambridge.

Runciman, J.C.S., (abridged ed.), 1980, The First Crusade, Cambridge University Press, Cambridge.

Sanutus, M., 1611, Liber Secretorum Fidelium Crucis, Typis Wechelianis, Apud heredes loannis Aubrii.

Scott, W., 1825, Tales of the Crusaders, Archibald Constable and Co., Edinburgh.

Setton, K.M., 1969, A history of the Crusades. Vol. 1: The first hundred years, University of Wisconsin Press, Madison, WI.

Setton, K.M., 1985, A history of the Crusades: Volume V-The impact of the Crusades on the Near East, The University of Wisconsin Press, Madison.

Severy, M., 1983, 'The Byzantine Empire: Rome of the East', National Geographic 164(6), 709-766.

Shakespeare, W., 1597 [2012], The first part of King Henry the Fourth, Start Publishing LLC, New York.

Shakespeare, W., 1603 [2012], Othello, Start Publishing LLC, New York.

Siberry, E., 2000, The new Crusaders: Images of the Crusades in the 19th and early 20th centuries, Ashgate Publishing Limited, Hants.

Spedding, J. (ed.), 1860, The works of Francis Bacon, 15 vols., The Riverside Press, Cambridge. 
Tasso, T., 1581, Gerusalemme Liberata (Jerusalem delivered), ed. \& transl. A.M. Esolen 2000, The John Hopkins University Press, Baltimore.

Tyerman, C., 1998, The invention of the Crusades, Macmillan Press, Hampshire.

Tyerman, C., 2005, 'Interview: Christopher Tyerman discusses his book on the Crusades', viewed 19 November 2016, from www.npr.org/programs/wesun/ transcripts/2005/feb/050227.tyerman.html

Tyerman, C., 2006, God's war: A new history of the Crusades, Penguin Group, London.

Tyerman, C., 2011, The Debate on the Crusades, 1099-2010, Manchester University Press, Manchester.

Van Wijk, T. \& Spies, S.B. (eds.), 1985, Western Europe: From the decline of Rome to the Reformation, Academica, Pretoria.
Vertot, M., 1772, L'Histoire des Chevaliers Hospitaliers de Saint Jean de Jerusalem, Par la Compagnie, Amsterdam.

Voltaire (Francois-Marie Arouet), 1751 [1835], Essai sur les mœeurs et l'esprit des nations, Treuttel et Würtz, Oxford.

Voltaire (Francois-Marie Arouet), 1759, An essay on universal history, the manners, and spirit of nations, from the Reign of Charlemaign to the age of Lewis XIV, vol. 1, transl. Mr. Nugent, Lamb (opposite Katherine Street in the Strand), London.

Von Sybel, H.K.L., 1841, Geschichte des ersten Kreuzzugs, JHC Schreiner, Düsseldorf.

Wilken, F., 1807-1832, Geschichte der Kreuzzüge nach morgenländischen und abendländischen Berichten, 7 vols., Crusius, Leipzig. 